\title{
Management Practices for Whitefly and Thrips in Mungbean
}

\author{
M. S. Alama, M. Alia, M. M. Hossain', M.S. Hossainc, M. A. Islam, M. H. R. Hera ${ }^{*}$
}

aDepartment of Entomology, Faculty of Agriculture, Sher-e-Bangla Agricultural University, Dhaka-1207, Bangladesh

bCall Centre Officer, Agriculture Information Service, Khamarbari, Dhaka-1215, Bangladesh

cDepartment of Agricultural Chemistry, Faculty of Agriculture, Sher-e-Bangla Agricultural University, Dhaka-1207, Bangladesh

dSustainable Intensification Program, International Maize and Wheat Improvement Center, Dhaka, Bangladesh

ePlant Pathology Division, Bangladesh Rice Research Institute, Gazipur 1701, Bangladesh

*Corresponding Author Email: hasibhera22@gmail.com

\section{Doi: 10.2478/mjhr-2021-0009}

\section{Abstract:}

This experiment was conducted at the central farm of Sher-e-Bangla Agricultural University, [23.740 N latitude and 90.350 E longitude] Sher-e-Bangla Nagar, Dhaka, Bangladesh, during the period of March to May, 2014 to study the Whitefly and Thrips pest incidence in mungbean and their management practices BARI Mung- 5 was used as the test crop for this experiment. The experiment consists of the following treatments: $\mathrm{T}_{1}$ : Nitro $505 \mathrm{EC}$ (Chloropyrifos+Cypermethrin) @ $2 \mathrm{ml} / \mathrm{L}$ of water at 10 days interval; T2: Casper 5 SG (Emamectin Benzoate) @ 2gm/L; T3: Voliam Flexi (Thiamethoxam+Chlorantraniliprole) @ $0.25 \mathrm{ml} / \mathrm{L} ; \mathrm{T}_{4}$ : Tapnor 40 EC (Dimethoate) @ $2.0 \mathrm{ml} / \mathrm{L} ; \mathrm{T}_{5}$ : Allion $2.5 \mathrm{EC}$ (Lamda-Cyhalothrin) @; T6: Admire 200SL (Imidachorpid) @ $0.25 \mathrm{ml} /$ Land T: Control. The experiment was laid out in Randomized Complete Block Design (RCBD) with three replications. The lowest number of whitefly infestation per plant in the vegetative stage (4.18) and reproductive stage (2.13) was recorded from T6 treatment, whereas the highest (14.44) and (8.10) was recorded from $\mathrm{T}_{7}$ treatment in respective stage. Thrips infestation was higher (6.32) per 5 flower was recorded from $\mathrm{T}_{7}$ treatment whereas lower infestation (1.88) per 10 flower was recorded from $\mathrm{T}_{6}$. The lowest yield per hectare (1.27 ton) was found in $\mathrm{T}_{7}$ and lowest benefit cost ratio (4.16) was found in $\mathrm{T}_{5}$ whereas highest yield per hectare (1.53 ton) was found in $\mathrm{T}_{6}$ and highest benefit cost ratio (12.81) was found in $\mathrm{T}_{3}$ treatment. Among the management practices for controlling whitefly and thrips of mungbean Admire 200SL @ 0.25 ml/L of water was more effective which was followed by Voliam Flexi (Thiamethoxam+Chlorantraniliprole) @ $0.25 \mathrm{ml} / \mathrm{L}$ of water Farmers should use Admire 200SL(Imidachorpid) @ $0.25 \mathrm{ml} / \mathrm{L}$ of water at 10 days interval for controlling whitefly and thrips in mungbean.

Keyword: Whitefly, Thrips, Management practices, Growth, Yield.

\subsection{Introduction}

Mungbean (Vigna radiate L. Wilczek) belonging to the family Leguminosae and sub-family Papilionaceae is one of the most important pulse crops in tropical and sub-tropical regions. The area under pulse crops in Bangladesh is 0.372 million hectares with a production of 0.387 million tons, where mungbean is cultivated in the area of 0.041 million hectares with production of 0.035 million tons [1]. It is considered as a quality pulse in the country but production per unit area is very low (736 kg/ha) as compared to other countries of the world [2]. Although mungbean plays an important role to supplement protein in the cereal-based low-protein diet of the people of Bangladesh, the acreage production of mungbean is gradually declining [1]. The crop has many advantages in the cropping system because of its rapid growth and early maturation. It can also fix atmospheric nitrogen through symbiotic relationship with soil bacteria and improve the soil fertility [3]. It ranks fifth both in acreage and production and contributes $6.5 \%$ of the total pulse production in Bangladesh [4]. It contains 51\% carbohydrate, $26 \%$ protein, $10 \%$ water, $4 \%$ minerals and $3 \%$ vitamins.

Management practices of mungbean is very easy with minimum tillage, local varieties with no or minimum fertilizers, without pest management and very early or very late sowing, no practicing of irrigation and drainage facilities etc.

All these factors are responsible for the low yield of mungbean which is incomparable with the yields of developed countries across the world [5]. A number of agronomic practices have been found to influence the yield of pulse crops [6]. Management of insect pest is one of the most important practices among them.

Many insect pest species attack mungbean throughout the cropping period in a mungbean field and several species of insect pests may be feeding in a plant. This makes it difficult to evaluate the economic importance of individual species. Several insect pests have been reported to infest mungbean and damage the seedlings, leaves, stems, flowers, buds, pods causing considerable losses $[7,8,9]$. The most damaging insect pests of mungbean recorded so far are stemfly [10,11], jassid [12,13], whitefly [14,15], thrips [14, 16], hairy caterpillar [14] and pod borer [14, 17]. Stemfly attack mainly the crop by feeding on tender stems at seedling stage, although it may attack at any stage of the crop. In mungbean; upto $97 \%$ plants were found to be infested by stemfly [18].

The whitefly causes damage to the plants by feeding on the leaf with stylets inserted into the leaf tissue. Whitefly reduces crop yield and acts as a vector of viral pathogens [19]. Thrips is associated mostly with the damage of tender buds and flowers of mungbean [11]. Chhabra and Kooner [16] have reported extensive damage to the summer mungbean due to flower shedding caused by thrips.

For the management of mungbean insect pests, many options such as chemical, cultural, mechanical, biological etc. are available. Chemical control is generally being advocated for the management of insect pests of mungbean. Soil application of Furadan $3 \mathrm{G} @ 1.5 \mathrm{~kg}$ a.i. ha-1 just prior to sowing followed by foliar application of Azodrin 40 EC @ 0.07\% at 50\% flowering protected the crop ensured higher yield [20]. Cypermethrin or Cymbush @ 0.008\% applied at flowering and again at podding were effective against pod borer [21]. In controlling stemfly, foliar sprays have been found to be more effective than granular forms of Carbofuran [22]. Studies have been found feasible to manage insect pests of mungbean through non-chemical methods such as use of botanicals [23]. Plant products were found to be effective against various pests [24]. Generally the farmers of Bangladesh do not spray chemicals to control the insect pest complex of mungbean due to its low profit margin. For this reason, several chemicals for different insect pests may not be acceptable to growers although, they are highly reluctant to follow pest control measure. The use of chemicals leds to impose certain well known 
undesirable side effects including environmental pollution, resurgence, resistance to pesticides, and development of high pesticide residues. Under the above perspective for the effective control of mungbean pests the present study has been undertaken - i) to document the abundance and severity by damage whitefly and thrips and ii) to find out the relationship between incidence of whitefly and thrips with mungbean yield and iii) to find out the most suitable insecticide for the management of insect pests of mungbean.

\subsection{Materials and Methods}

\subsection{Description of the experimental site}

\subsubsection{Location and Time}

The present research was conducted at the research field of Sher-e-Bangla Agricultural University, Sher-e-Bangla Nagar, Dhaka during the period from March to May, 2014. The experimental area is located at $23.740 \mathrm{~N}$ latitude and 90.350 E longitude with an elevation of $8.2 \mathrm{~m}$ from the sea level [25].

\subsubsection{Soil}

The soil of the experimental area was general soil type series of shallow red brown terrace soils under Tejgaon series. Upper level soils were clay loam in texture, olive-gray through common fine to medium distinct dark yellowish brown mottles under the Agro-ecological Zone (AEZ- 28) and belonged to the Madhupur Tract [26]. The selected plot was above flood level and sufficient sunshine having available irrigation and drainage system during the experimental period. Soil samples from 0-15 cm depths were collected from experimental field. The analyses were done from Soil Resources Development Institute (SRDI), Dhaka. The experimental plot was also high land, fertile, well drained and having pH 5.8. The physicochemical property and nutrient status of soil of the experimental plots are given in Appendix 1.

\subsubsection{Climate and Weather}

The experimental area is situated in the sub-tropical climatic zone and characterized by heavy rainfall during the months of March to May ( kharif season) and October to March (robi season) is characterized by comparatively low temperature and plenty of sunshine hour from November to February. The detailed meteorological data in respect to temperature, relative humidity and total rainfall was recorded by the weather station of Bangladesh, Sher-e-Bangla Nagar, Dhaka during the period of study which have been presented in Appendix II.

\subsection{Experiment details}

\subsubsection{Variety and treatments}

Mungbean variety BARI Mung-5 was used as experimental materials for the study and the seed of the variety of this experiment collected from Bangladesh Agricultural Research Institute (BARI)., Joydebpur, Gazipur. The experiment comprised seven treatments including an untreated control. The details of the treatments are given below:

$\mathrm{T}_{1}=$ Nitro 505EC (Chloropyrifos + Cypermethrin) @ $2 \mathrm{ml} / \mathrm{L}$ of water at 10 days interval;

$\mathrm{T}_{2}=$ Casper 5 SG(Emamectin Benzoate) @ 2gm/L of water at 10 days interval;

$\mathrm{T}_{3}=$ VoliamFlexi(Thiamethoxam+Chlorantraniliprole) @ $0.25 \mathrm{ml} / \mathrm{L}$ of water at 10 days interval;

$\mathrm{T}_{4}=$ Tapnor 40 EC(Dimethoate) @ $2.0 \mathrm{ml} / \mathrm{L}$ of waterat 10 days interval;

$\mathrm{T}_{5}=$ Allion $2.5 \mathrm{EC}($ Lamda-Cyhalothrin) @ $2.0 \mathrm{ml} / \mathrm{L}$ of water at 10 days interval;

$\mathrm{T}_{6}=$ Admire 200SL(Imidachorpid) @ $0.25 \mathrm{ml} / \mathrm{L}$ of water at 10 days interval and

$\mathrm{T}_{7}=$ No Insecticides

\subsubsection{Experimental design and layout}

The experiment consisted of BARI Mung-5 and was laid out in Randomized Complete Block Design (RCBD) with three replications which were divided into seven equal blocks. There were $21(3 \times 7)$ unit plots altogether in the experiment. The size of each unit plot was $3 \mathrm{~m} \times 3 \mathrm{~m}$. Block to Block and plot to plot distances were $1 \mathrm{~m}$ and $0.5 \mathrm{~m}$, respectively. The treatments of the experiment was distributed randomly among the experimental plots.

\subsubsection{Land preparation}

Power tiller was used for the preparation of the experimental field. It was exposed to sunshine for 7 days prior to the next ploughing. Ther eafter, the land was ploughed and cross-ploughed to obtain good tilth. Deep ploughing was done to produce a good tilth, which was necessary to get better yield of this crop.

\subsubsection{Fertilizers and seed sowing}

The fertilizers were applied as per fertilizers recommendation guide [27]. Before planting the seeds were treated with Vitavex-200 @ 0.25\% to prevent seeds from the attack of soil borne disease. Furadan @1.2 kg ha-1 was also used as per treatment against wireworm and mole cricket. Treated mature 4-5 seeds of mungbean were sown in each hole by hand. Seeds were sown on 13th March, 2014. The row to row and plant to plant distances were $30 \mathrm{~cm}$ and $6 \mathrm{cmrespectively.} \mathrm{Seeds} \mathrm{were} \mathrm{placed} \mathrm{at} \mathrm{about} 5 \mathrm{~cm}$ depth from the soil surface. Three seeds were sown in each hole.

\subsubsection{Intercultural operations}

Overcrowded seedlings were thinned out two times. First thinning was done after 15 days of sowing which was done to remove unhealthy and lineless seedlings. The second thinning was done 10 days after the first thinning. Gap filling were done where seeds failed to germinate. The gaps were filled in within two weeks after germination of seeds. Some common weeds are found in the mungbean field. First weeding was done at 30 DAS and then once a week to keep the plots free from weeds and to keep the soil loose and aerated. The irrigation was done after the first weeding. The experimental crop 
was infected with sucking pests and diseases and no fungicide was used. They attacked at the early growing stages of seedlings till the harvest period. Various chemical spray as water solution was applied 8 times at 10 days interval as a treatment from the germination to harvest period to control these sucking pests and diseases.

\title{
2.3 Data collection and calculation
}

\subsubsection{Number of whitefly and thrips and their reduction percentage}

Number of whitefly and thrips were recorded at vegetative and reproductive stages . Five plants were randomly selected for the collection of data. Data on number of insects were recorded at an interval of 10 days commencing from first incidence and continued up to 13 weeks (total 8 times). Reduction percentage was also recorded on the basis of control plant where the maximum number of whitefly and thrips attacked. The following formula were used for taking the reduction percentage:

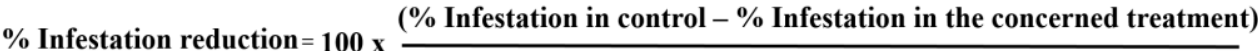

\author{
$\%$ Infestation in control
}

\subsubsection{Determination of pod infestation by number and infestation reduction over control}

All the healthy and infested pods were counted from 5 randomly selected plants from middle rows of each plot and then examined. The collected data were divided into early, mid and late podding stage. The healthy and infested pods were counted at early, mid and late stage and the percentage of pod damage was calculated using the following formula:

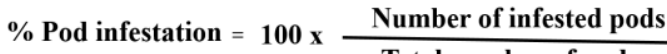 \\ Total number of pods \\ $\%$ Infestation reduction $=100 \times \frac{(\% \text { Infestation in control }-\% \text { Infestation in the concerned treatment })}{}$ \\ $\%$ Infestation in control
}

\subsubsection{Growth data}

Plant height was measured in centimeter by a meter scale at harvest and their average data was recorded per replication. Data were also recorded as the average of randomly selected 5 plants from the inner rows of each plot. Similarly, number of branches per plant ${ }^{-1}$, number of leaves per plant ${ }^{-1}$ data at before and after flowering and total number of pods per plant were counted by separating all pods from sample plants and average counted.

\subsubsection{Yield data}

\subsubsection{1000-grain weight (g)}

One thousand grains were randomly counted and selected from the stock seed and weighed in gram by digital electric balance. It was expressed as 1000 seed weight in gram (g).

\subsubsection{Yield plot ${ }^{-1}(\mathrm{~kg})$}

Seed yield were recorded from randomly selected fives pods. After harvesting the plant was sun-dried and threshed. Seed were properly sun-dried and their weights recorded. Seed yield was then converted to g plot $^{-1}$.

\subsubsection{Fruits yield hectare ${ }^{-1}$}

Fruits per plot were converted into hectare and the weight of fruits per hectare was calculated and expressed in ton.

\subsubsection{Statistical analysis}

The data obtained from experiment on various parameters were statistically analyzed in MSTAT-C computer program [32]. The mean values for all the parameters were calculated and the analysis of variance for the characters was accomplished by Duncan's Multiple Range Test (DMRT) and the significance of difference between pair of means was tested by the Least Significant Differences (LSD) test at $5 \%$ levels of probability [33]. Benefit cost ratio was also calculated.

Benefit cost ratio $(\mathrm{BCR})=$

$\frac{\text { Net return }}{\text { Cost of pest management }}$

\subsection{Results and Discussion}

\subsection{Effect of treatments on incidence of whitefly on mungbean}

The population incidence of whitefly at vegetative and reproductive stage and thrips infestation per 10 flowers of mungbean under different treatments has been shown in Table 1 . The data shows that the lowest number of whitefly (4.18/plant at vegetative and $2.13 /$ plant at reproductive stage) was observed in $\mathrm{T}_{6}$ (Admire 200SL) treated plot followed by $\mathrm{T}_{3}$ (Voliam Flexi) treated plot (5.22/plant at vegetative and 3.90/plant at reproductive stage) having significant differences between them. Other insecticides have an intermediate number of whitefly. The highest number of whitefly $(14.44 /$ plant at vegetative and 8.10 at reproductive stage) was found in the control plot and was significantly higher than all other treated plots. Similarly Admire 200SL showed the best performance in reduction of whitefly population over control followed by Voliam Flexi. Others showed intermediate results in reducing whitefly population over control. The lowest number of thrips per 10 flowers (1.88) was found from $\mathrm{T}_{6}$ (Admire 200SL) which was followed (2.98) by $\mathrm{T}_{3}$ (Voliam Flexi), while the highest number of thrips per 10 flowers (6.32) was observed from $\mathrm{T}_{7}$ (control condition) which was followed (4.34) by $\mathrm{T}_{1}$ (Nitro 505EC). 
In case of the reduction in the number of whitefly per plant, the highest value in vegetative (71.05\%) and reproductive stage (73.70\%) was recorded for the treatment $\mathrm{T}_{6}$ and the lowest value in vegetative (34.07\%) and reproductive stage (18.52\%) from $\mathrm{T}_{1}$ treatment while in case of reduction in number of thrips per 10 flowers over control, the highest value $(70.25 \%)$ was recorded for the treatment $\mathrm{T}_{6}$ and the lowest value $(31.33 \%)$ from $\mathrm{T}_{1}$ treatment

The results of the study reveal that all the insecticides significantly reduced whitefly and thrips population infesting mungbean. However, Admire 200SL was the most effective insecticide and Voliam Flexi was second most effective insecticides but Tapnor 40 EC, Allion 2.5 EC, Casper 5 SG and Nitro 505EC were less effective insecticides in field condition. The order of effectiveness is Admire 200SL $>$ Voliam Flexi $>$ Tapnor $40 \mathrm{EC}>$ Allion $2.5 \mathrm{EC}>\mathrm{Casper} 5 \mathrm{SG}>\mathrm{Nitro} 505 \mathrm{EC}$.

Table 1: Population incidence of whitefly on mungbean under different treatments at vegetative and reproductive stage

\begin{tabular}{|c|c|c|c|c|c|c|}
\hline \multirow{3}{*}{ Treatments } & \multicolumn{4}{|c|}{$\begin{array}{c}\text { Whitefly } \\
\text { Reproductive stage }\end{array}$} & \multirow{2}{*}{\multicolumn{2}{|c|}{ Thrips }} \\
\hline & \multicolumn{2}{|c|}{ Vegetative stage } & \multicolumn{2}{|c|}{ Reproductive stage } & & \\
\hline & $\begin{array}{l}\text { No. of whitefly } \\
\text { Plant }^{-1}\end{array}$ & $\begin{array}{l}\% \text { reduction } \\
\text { over control }\end{array}$ & $\begin{array}{l}\text { No. of whitefly } \\
\text { Plant }^{-1}\end{array}$ & $\begin{array}{c}\% \text { reduction } \\
\text { over control }\end{array}$ & $\begin{array}{l}\text { Number of } \\
\text { thrips per } 10 \\
\text { flowers }\end{array}$ & $\begin{array}{c}\text { \% reduction } \\
\text { over control }\end{array}$ \\
\hline$T_{1}$ & $9.52 \mathrm{~b}$ & 34.07 & $6.60 \mathrm{ab}$ & 18.52 & $4.34 \mathrm{~b}$ & 31.33 \\
\hline $\mathbf{T}_{2}$ & $9.02 \mathrm{~b}$ & 37.53 & $6.10 \mathrm{bc}$ & 24.69 & $4.12 \mathrm{~b}$ & 34.81 \\
\hline $\mathbf{T}_{4}$ & $6.68 \mathrm{~cd}$ & 53.74 & $4.45 \mathrm{bcd}$ & 45.06 & $3.32 \mathrm{~b}$ & 47.47 \\
\hline $\mathbf{T}_{5}$ & $8.31 \mathrm{bc}$ & 42.45 & $5.90 \mathrm{bc}$ & 27.16 & $3.88 \mathrm{~b}$ & 38.61 \\
\hline$T_{6}$ & $4.18 \mathrm{e}$ & 71.05 & $2.13 \mathrm{~d}$ & 73.70 & $1.88 \mathrm{c}$ & 70.25 \\
\hline Control & $14.44 \mathrm{a}$ & -- & $8.10 \mathrm{a}$ & -- & $6.32 \mathrm{a}$ & -- \\
\hline CV (\%) & 2.075 & -- & 1.91 & -- & 1.378 & -- \\
\hline
\end{tabular}

In a column, means having different letter(s) are significantly different at $5 \%$ level of probability.

The result of the present study was in accordance with the findings of other scientist like Mustafa [28], Mohan and Katiray [29], Sreekanth et al.[22] and Ganapathy and Karuppiah [30]. According to them insecticides application like imidaclorpid and thiamethoxam reduce whitefly on mungbean and increase the yield.

\subsection{Pod bearing status at early fruiting stage and late fruiting stage}

Number of healthy pods, infested pods and percent infestation of mungbean pods showed statistically significant differences at early pod stage and late pod stage, for different management practices under the present trial (Table 2). The highest number of healthy pods plant ${ }^{-1}$ (22.83) was recorded in $\mathrm{T}_{6}(\mathrm{Admire}$ 200SL) treatment which was statistically identical (19.01) with $\mathrm{T}_{3}$ (Voliam Flexi). Similarly at late pod stage maximum number (21.04) was recorded in $\mathrm{T}_{6}$ (Admire 200SL) treatment which was followed (19.22) by $\mathrm{T}_{3}$ (Voliam Flexi). On the other hand, the lowest number (14.14) was recorded in $\mathrm{T}_{7}$ (Control) treatment which was statistically similar (15.43) to $\mathrm{T}_{1}$ (Nitro 505EC). The highest number of infested pods plant ${ }^{-1}(7.20)$ was recorded in $\mathrm{T}_{7}$ treatment followed by $\mathrm{T}_{1}$ (5.40) whereas the lowest number (2.40) was recorded in $\mathrm{T}_{6}$ treatment which was followed (3.00) by $\mathrm{T}_{3}$. The highest percentage of infested pods plant ${ }^{-1}$ in number (33.81\%) was recorded in $\mathrm{T}_{7}$ treatment which was followed (25.98\%) by $\mathrm{T}_{1}$. Again, the lowest infestationnumber (9.58\%) was recorded in $\mathrm{T}_{6}$. Mungbean pod infestation percentage reduction over control at early pod stage in number was estimated for different management practices and the highest value (71.67\%) was recorded for the treatment $\mathrm{T}_{6}$ and the lowest value $(23.16 \%)$ from $\mathrm{T}_{1}$ treatment.

On the other hand, the lowest number (12.74) was recorded in $\mathrm{T}_{7}$ (Control) treatment which was followed (61.63) by $\mathrm{T}_{1}$ (Nitro 505EC). At late pod stage, the highest number of infested pods plant ${ }^{1}$ (7.83) was recorded in $\mathrm{T}_{7}$ treatment followed by $\mathrm{T}_{1}$ (Nitro 505EC) whereas the lowest number (2.03) was recorded in $\mathrm{T}_{6}$ treatment which was followed (2.50) by $\mathrm{T}_{3}$. The highest percent of infested pods plant ${ }^{-1}$ in number (38.16\%) was recorded in $\mathrm{T}_{7}$ treatment which was followed (27.07\%) by $\mathrm{T}_{1}$. Again, the lowest infestation percent in number (8.87\%) was recorded in $\mathrm{T}_{6}$ treatment which was followed (11.59\%) with $\mathrm{T}_{3}$. Mungbean pod infestation percentage reduction over control at mid pod stage in

Table 2: Effect of different management practices on the damage severity of pod borer attacking mungbean, at early pod stage and late pod stage

\begin{tabular}{|c|c|c|c|c|c|c|c|}
\hline \multirow{2}{*}{ Treatments } & \multicolumn{4}{|c|}{ Early pod stage } & \multicolumn{3}{c|}{ Late pod stage per plant \% Infestation Reduction of } \\
infestation over control (\%)
\end{tabular}


In a column means having similar letter(s) are statistically identical and those having dissimilar letter(s) differ significantly as per 0.05 level of probability number was estimated for different management practices and the highest value (76.76\%) was recorded for the treatment $\mathrm{T}_{6}$ and the lowest value (29.06\%) from $\mathrm{T}_{1}$ treatment. From the findings it is revealed that at late pod stage, spraying of Admire 200SL (Imidachorpid) resulted in maximum number of healthy pods and minimum number infested pods as well as lowest percent of pod infestation in number followed by Voliam Flexi (Thiamethoxam+Chlorantraniliprole), while in the Control treatment gave the minimum number of healthy pods, maximum number of infested pods and highest percentage of infestation under the trail followed by Nitro 505EC (Chloropyrifos + Cypermethrin).

Ganapathy and Karuppiah [30], Mustafa [28], Sreekanth et al. [22]also agree with the experiment. They showed significant increase of pod yield by controlling whitefly and thrips population.

\subsection{Effect of different treatment on growth of mungbean}

\subsubsection{Plant height at harvest}

Plant height of mungbean at harvest for controlling whitefly and thrips by using different management practices showed statistically significant differences (Table 3). The longest plant $(48.89 \mathrm{~cm})$ was recorded in $\mathrm{T}_{6}$ treatment which was followed $(46.82 \mathrm{~cm})$ by $\mathrm{T}_{3}$, while the shortest plant $(40.92$ $\mathrm{cm}$ ) was recorded in $\mathrm{T}_{7}$ treatment. Plant height increase in the control was estimated for different management practices and the highest value (19.48\%) was recorded for the treatment $\mathrm{T}_{6}$ and the lowest value (3.32\%) from $\mathrm{T}_{1}$ treatment.

\subsubsection{Number of branch plant ${ }^{-1}$ and Number of leaves plant ${ }^{-1}$}

Branch plant ${ }^{-1}$ was significantly affected by different treatment. Among the treatments, the maximum number of branch (9.46) was found from the treatment Admire 200SL @ $0.25 \mathrm{ml} / \mathrm{L}$ of water, because minimum number and more reduction of sucking insect pests was recorded which was closely followed (8.37) by Voliam Flexi . On the other hand, the minimum number of branch (7.13) was recorded from the control treatment where maximum number of sucking insect pests was found (Fig. 1).

The result indicates that application of chemical insecticides reduced the pest infestation in mungbean, although their performance was different. Admire 200SL showed the best performance and Voliam Flexi was second in effectiveness as an insecticides . The application of insecticides reduced the population of sucking insects of mungbean and thus the number of branches increased .

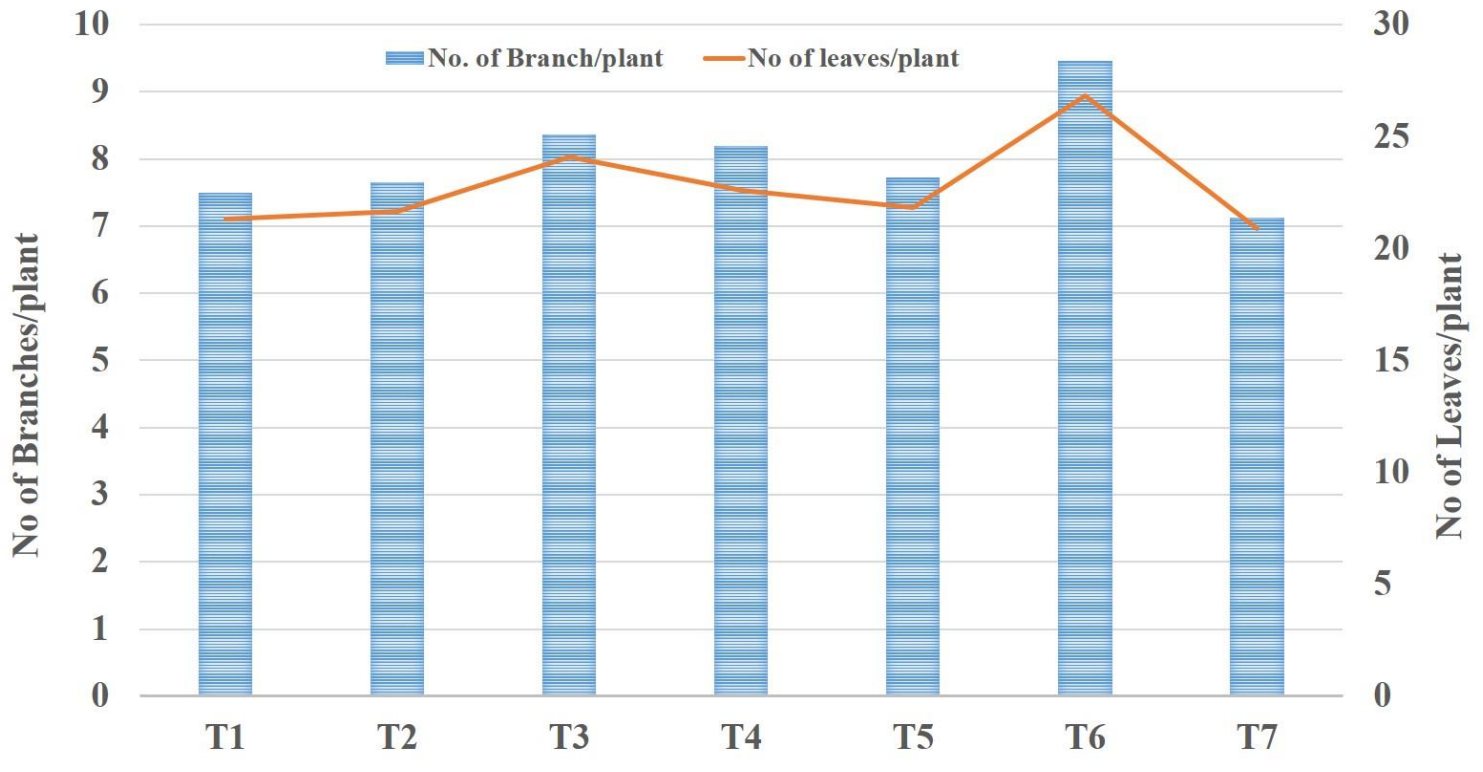

Treatment

Figure 1: Effect of treatments on branch and no. of leaves of mungbean plant

The maximum number of leaves (26.82) was found from the treatment Admire 200SL because reduction in the number of sucking insect pests was recorded which was closely followed by Voliam Flexi (24.09). On the other hand, minimum number of leaves (20.91) was recorded from the control treatment where maximum number of sucking insect pests was found (Fig. 1).The result indicates that application of chemical insecticides reduces the pest infestation in mungbean although their performance was different. Admire 200SL showed the best performance and Voliam Flexi was the second effective insecticides. The application of insecticides reduced the population of sucking insects of mungbean and thus number of leaves increased .

\subsection{Effect of chemical insecticides and plant extracts on the yield of mungbean}

\subsubsection{Number of pods plant ${ }^{-1}$}

Number of pods plant ${ }^{-1}$ was significantly influenced by the effect of various insecticides. Overall, the treatment by Admire 200SL produced the maximum number of pods plant ${ }^{-1}$ (75.86) and it was followed by Voliam Flexi (68.49) where the maximum reduction of sucking insects was taken. Among the other 
treatments, the minimum number of pods plant ${ }^{-1}$ (61.44) was recorded in untreated or the control treatment (Table 1). These results agree with the reports of several researchers Jahangir Shah et al. [31] who reported that pods/plant and seed yield kg ha ${ }^{-1}$ varied significantly among different insecticides. Out of all the insecticides used in this study, Imidacloprid treated plots had notably the highest yield of (1563 kg ha-1) while the lowest seed yield (1056 kg/ha) was obtained from the control plots where no insecticide was applied.

\subsubsection{0-seed weight (g)}

Effect of chemical insecticides and botanical extract showed significant variation in respect of 1000 -seed weight. Among the treatments, Admire $200 \mathrm{SL}$ produced the highest reduction of sucking insects as well as the highest weight of 1000 - seeds $(43.30 \mathrm{~g})$ and it was followed by the second highest ( 42.05 g) treatment of Voliam Flexi. Maximum sucking pest reduced the yield because of the lowest 1000 -seeds weight (38.5 g) was recorded in control treatment where the minimum reduction of sucking pests was obtained (Figure 2)

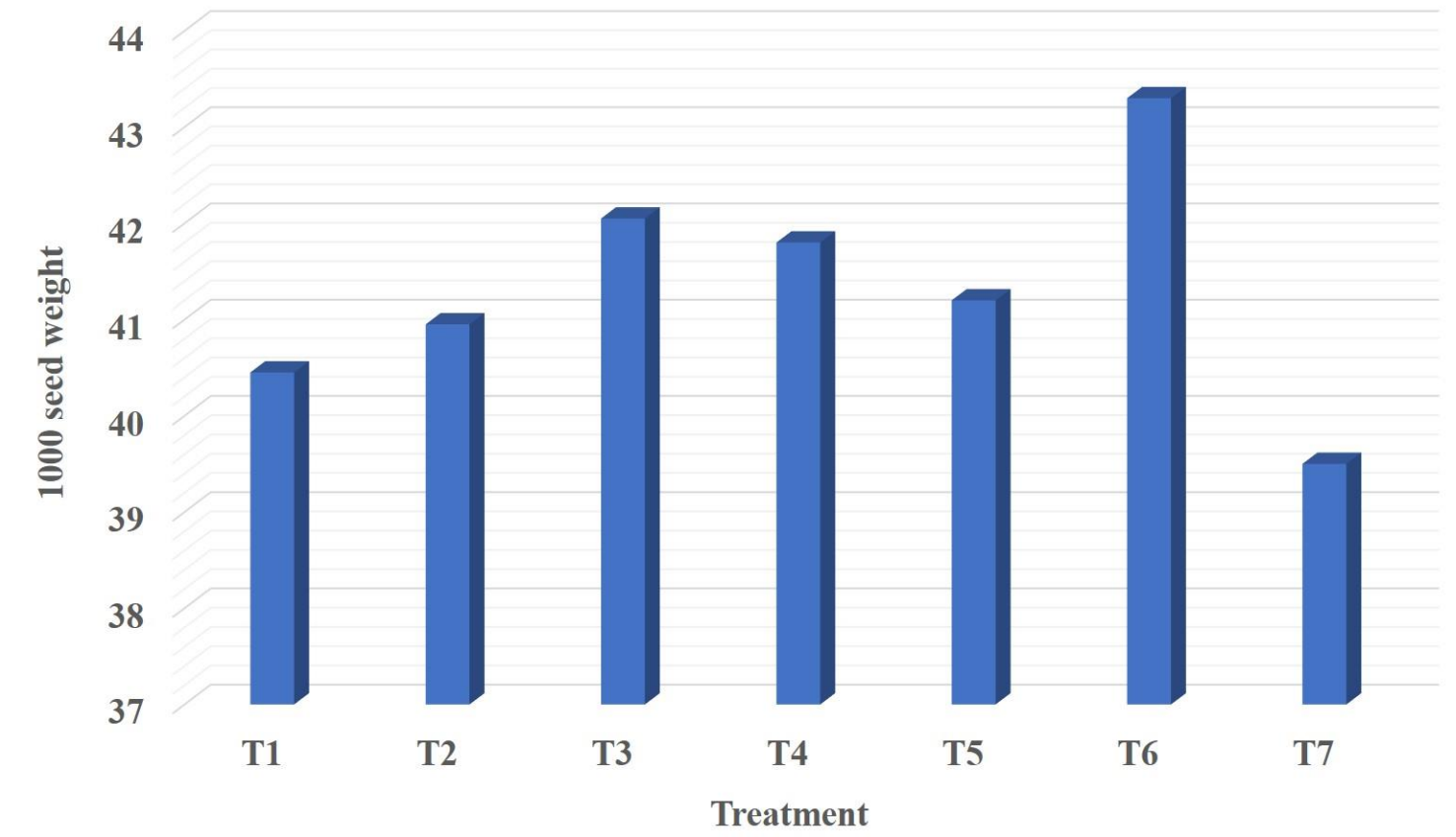

T1= Nitro 505EC | T2= Casper 5 SG | T3= Voliam Flexi | T4= Tapnor 40 EC | T5= Allion 2.5 EC | T6= Admire 200SL | T7= Control

Figure 2: Effect of treatments on 1000 seed weight of mungbean

\subsubsection{Yield per plant}

To control whitefly and thrips by using different management practices, the yield per plant of mungbean showed significant differences (Figure 3 ). The highest yield per plant ( $3.2 \mathrm{~g}$ ) was recorded in $\mathrm{T}_{6}$ treatment which was followed ( $2.91 \mathrm{~g}$ ) by $\mathrm{T}_{3}$, whereas the lowest yield ( $2.43 \mathrm{~g}$ ) in $\mathrm{T}_{7}$ treatment followed by $\mathrm{T}_{1}(2.52 \mathrm{~g})$. 


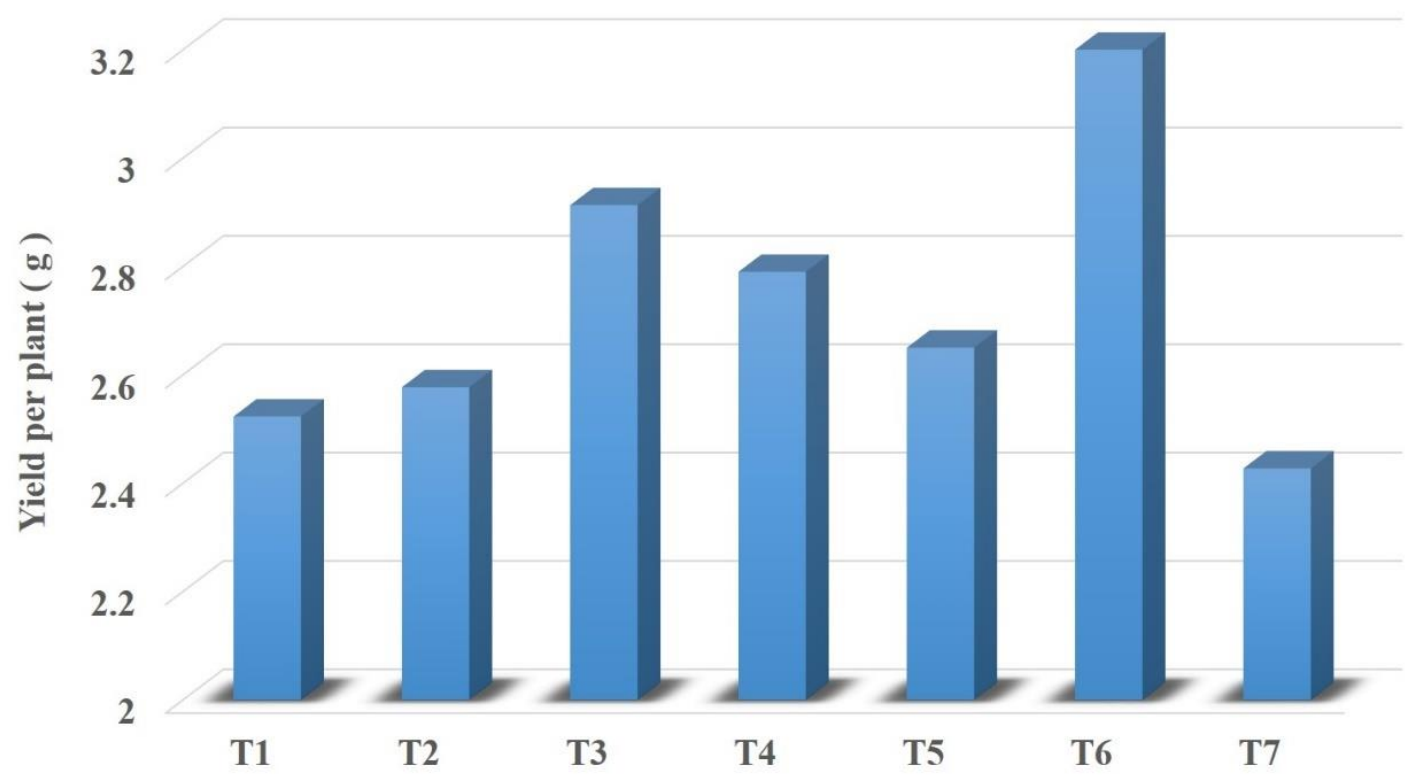

Treatments

$\mathrm{T} 1=$ Nitro 505EC $\quad \mathrm{T} 2=$ Casper $5 \mathrm{SG} \quad \mathrm{T} 3=$ Voliam Flexi $\quad \mathrm{T} 4=$ Tapnor $40 \mathrm{EC} \quad \mathrm{T} 5=$ Allion $2.5 \mathrm{EC} \quad \mathrm{T} 6=$ Admire 200SL $\quad \mathrm{T} 7=\mathrm{Control}$

Figure 3: Effect of treatments on yield per plant of mungbean

Table 3: Effect of different management practices on plant height, number of pods/plant and yield per hectare of mungbean

\begin{tabular}{|c|c|c|c|c|c|c|}
\hline \multirow[b]{2}{*}{ Treatments } & \multirow{2}{*}{$\begin{array}{c}\text { Plant } \\
\text { height }\end{array}$} & \multirow[b]{2}{*}{ Number of pods/plant } & \multirow{2}{*}{$\begin{array}{c}\text { Yield } \\
\text { (t/ha) }\end{array}$} & \multicolumn{3}{|c|}{ Increase over control (\%) } \\
\hline & & & & $\begin{array}{c}\text { Plant } \\
\text { height }\end{array}$ & $\begin{array}{l}\text { Number of } \\
\text { pods/plant }\end{array}$ & $\begin{array}{l}\text { Yield } \\
\text { (t/ha) }\end{array}$ \\
\hline $\mathrm{T} 1$ & $42.28 \mathrm{bc}$ & $62.12 \mathrm{c}$ & $1.48 \mathrm{~d}$ & 3.32 & 1.11 & 16.54 \\
\hline $\mathrm{T} 2$ & $43.39 \mathrm{bc}$ & $63.14 \mathrm{c}$ & $1.50 \mathrm{~d}$ & 6.04 & 2.77 & 18.11 \\
\hline T3 & $46.82 \mathrm{ab}$ & $68.49 \mathrm{a}$ & $1.74 \mathrm{~b}$ & 14.41 & 11.48 & 37.01 \\
\hline $\mathrm{T} 4$ & $45.14 \mathrm{~b}$ & $67.17 \mathrm{~b}$ & $1.61 \mathrm{c}$ & 10.31 & 9.32 & 26.77 \\
\hline T6 & $48.89 a$ & $75.86 \mathrm{a}$ & $1.91 \mathrm{a}$ & 19.48 & 23.44 & 50.39 \\
\hline $\mathrm{T} 7$ & $40.92 \mathrm{c}$ & $61.44 \mathrm{~d}$ & $1.27 \mathrm{e}$ & -- & -- & -- \\
\hline CV(\%) & 2.96 & 0.55 & 0.079 & -- & -- & -- \\
\hline
\end{tabular}

In a column means having similar letter(s) are statistically identical and those having dissimilar letter(s) differ significantly as per 0.05 level of probability

$\mathrm{T}_{1}=$ Nitro 505EC (Chloropyrifos + Cypermethrin) @ $2 \mathrm{ml} / \mathrm{L}$ of water at 10 days interval;

$\mathrm{T}_{2}=$ Casper 5 SG(Emamectin Benzoate) @ 2 gm/L of water at 10 days interval;

$\mathrm{T}_{3}=$ Voliam Flexi(Thiamethoxam+Chlorantraniliprole) @ $0.25 \mathrm{ml} / \mathrm{L}$ of water at 10 days interval;

$\mathrm{T}_{4}=$ Tapnor $40 \mathrm{EC}($ Dimethoate) $@ 2.0 \mathrm{ml} / \mathrm{L}$ of water at 10 days interval;

$\mathrm{T}_{5}=$ Allion $2.5 \mathrm{EC}($ Lamda-Cyhalothrin) @ $2.0 \mathrm{ml} / \mathrm{L}$ of water at 10 days interval;

$\mathrm{T}_{6}=$ Admire 200SL(Imidachorpid) @ $0.25 \mathrm{ml} / \mathrm{L}$ of water at 10 days interval and

$\mathrm{T}_{7}=$ Control

\subsubsection{Yield per hectare}

To control whitefly and thrips by using different management practices, the yield per hectare of mungbean showed significant differences (Table 3 ). The highest yield per hectare (1.91 ton) was recorded in $\mathrm{T}_{6}$ treatment which was followed (1.75 ton) by $\mathrm{T}_{3}$, whereas the lowest yield (1.27 ton) in $\mathrm{T}_{7}$ 
treatment. Yield per hectare of mungbean increase under control was estimated for different management practices and the highest value (50.39\%) was recorded from $\mathrm{T}_{6}$ and the lowest value $(16.54 \%)$ from $\mathrm{T}_{1}$ treatment.

\subsection{Economic analysis}

The analysis was done in order to find out the most profitable management practices based on cost and benefit of various components. The results of economic analysis of mungbean cultivation showed that the highest net benefit of Tk. 123620 ha-1 $^{-1}$ was obtained in T6 treatment and the second highest Tk. 112980 ha $^{-1}$, was found in T3 (Table 4). The highest benefit cost ratio (12.81) was estimated for T3 treatment and the lowest (4.16) for T5 treatment under the trial. The highest BCR found in the treatment T3, may be due to the minimum pest infestation to the other treatment components and the better yield of this treatment. According to Rahman [21] spraying of Fenitrothion $0.1 \%$ at the flowering stage and the second spray either at an interval of 15 days or at podding offered the highest cost-benefit ratio.

Table 4: Cost of mungbean production for different management practices of insect pests

\begin{tabular}{|c|c|c|c|c|c|}
\hline Treatments & $\begin{array}{c}\text { Cost of pest } \\
\text { Management (Tk.) }\end{array}$ & $\begin{array}{c}\text { Yield } \\
\text { (t/ha) }\end{array}$ & $\begin{array}{c}\text { Gross return } \\
\text { (Tk.) }\end{array}$ & $\begin{array}{c}\text { Net Return } \\
\text { (Tk.) }\end{array}$ & Benefit cost ratio \\
\hline $\mathbf{T}_{\mathbf{1}}$ & 18480 & 1.48 & 100800 & 82320 & 4.45 \\
\hline $\mathbf{T}_{\mathbf{2}}$ & 20160 & 1.50 & 105000 & 112980 & 4.21 \\
\hline $\mathbf{T}_{\mathbf{3}}$ & 8820 & 1.74 & 121800 & 94840 & 12.81 \\
\hline $\mathbf{T}_{\mathbf{4}}$ & 13440 & 1.61 & 112700 & 88620 & 7.39 \\
\hline $\mathbf{T}_{\mathbf{5}}$ & 21280 & 1.57 & 109900 & 123620 & 4.16 \\
\hline $\mathbf{T}_{\mathbf{6}}$ & 10080 & 1.91 & 133700 & 8890 & 12.26 \\
\hline $\mathbf{T}_{\mathbf{7}}$ & 0 & 1.27 & 101500 & & \\
\hline
\end{tabular}

Price of mungbean @ Tk.70/kg

$\mathrm{T}_{1}=$ Nitro 505EC (Chloropyrifos + Cypermethrin) @ $2 \mathrm{ml} / \mathrm{L}$ of water at 10 days interval;

$\mathrm{T}_{2}=$ Casper $5 \mathrm{SG}($ Emamectin Benzoate) @ $2 \mathrm{gm} / \mathrm{L}$ of water at 10 days interval;

$\mathrm{T}_{3}=$ Voliam Flexi(Thiamethoxam+Chlorantraniliprole) @ $0.25 \mathrm{ml} / \mathrm{L}$ of water at 10 days interval;

$\mathrm{T}_{4}=$ Tapnor $40 \mathrm{EC}($ Dimethoate) @ $2.0 \mathrm{ml} / \mathrm{L}$ of water at 10 days interval;

$\mathrm{T}_{5}=$ Allion $2.5 \mathrm{EC}($ Lamda-Cyhalothrin) @ $2.0 \mathrm{ml} / \mathrm{L}$ of water at 10 days interval;

$\mathrm{T}_{6}=$ Admire 200SL(Imidachorpid) @ $0.25 \mathrm{ml} / \mathrm{L}$ of water at 10 days interval and

$\mathrm{T}_{7}=$ Control

\subsection{Conclusion}

From the above findings it was revealed that Admire 200SL(Imidachorpid) @ $0.25 \mathrm{ml} / \mathrm{L}$ of water was more effective amongst the management practices for controlling whitefly and thrips of mungbean which was followed by Voliam Flexi (Thiamethoxam + Chlorantraniliprole) @ 0.25 ml/L of water. Considering the situation of the present experiment, further studies in the following areas may be suggested:

- Similar studies need to be conducted in different agro-ecological zones (AEZ) of Bangladesh for regional adaptability.

- Using chemical with different concentration may be used for further study for better output.

- Integrated pest management practices may be introduced for effective control of mungbean pest.

\subsection{References}

[1] BBS, "Statistical Yearbook of Bangladesh. Bangladesh Bureau of Statistics, Statistics Division", Ministry of Planning, Govt. of Peoples Republic of Bangladesh, Dhaka, Bangladesh, 2017.

[2] BBS, "Statistical year book of Bangladesh.26th Edit. Bangladesh bureau of Statistics, Planning division", Ministry of planning ,Govt. of the people's republic of Bangladesh, p. 143, 2006

[3] L.S. Yadav, P.R. Yadav, F.S. Poonia, "Effectiveness of certain insecticides against the insect pests of mungbean". Indian J. Plant. Prot, 7: 165-169. 1979.

[4] Anonymous, "Effect of sowing date and insecticides against stemfly and pod borer of blackgram", Annual Report, 1997/1998, Bangladesh Agricultural Research Institute (BARI), Joydebpur, Gazipur, Bangladesh, pp. 104-105, 1998

[5] FAO (Food and Agricultural Organization), "FAO Production Yearbook", Basic Data Unit, Statistic Division, FAO, Rome, Italy, 1999 
[6] S. Boztok, "Investigation on the effect of sowing date and verbalisation on seed production in early cauliflower cv. Ege". Universal Zirratfakultesi Dergis. 22; 89-99, 1985

[7] V.K. Sehgal, R. Ujagir, "Insect and pest management of mungbean in India". Mungbean: Proceedings of the Second International Symposium. Asian Vegetable Research and Development Centre, Shanhua, Taiwan, 1988

[8] M. Husain, “Anistakari Kit-patanga Daman (in Bengali)”. Bangla Academy. Dhaka, 220p, 1993

[9] M.A. Karim, M.M. Rahman, "Status of insect and vertebrate pest management research on pulses". Pp. 135-138. In: Proceedings of the Second National Workshop on Advances in Pulses Research in Bangladesh, 6-8 June 1989, Joydebpur, Bangladesh. Patancheru, A. P. 502324 , India. International Crops Research Institute for the Semi-Arid Tropics, 1991

[10] M.M. Rahman, "Evaluation of Sumithion as a component of an integrated pest management program to control insect pests of mungbean, Abstracts of for the Bangladesh Science Conference 12", Bangladesh Assoc. Adv. Sci. 1(1987): 38-39

[11] S.S. Lal, "A review of insect pests of mungbean and their control in India", Trop. Pest Management. 31(2): 105-114, 1985

[12] B. Baldev, S. Ramanujam, H.K. Jain, “Pulse crops”. Oxford \& IBH Publishing Co. Pvt. Ltd. New Delhi, pp. 229-258. 1988.

[13] J.P. Chaudhary, L.S. Yadav, R.S. Poonia, K.B. Rastogi, "Some observation on field populations of EmpoascakerriPruthi, a jasid pest on mungbean crop in Haryana", Haryana Agric, Univ. J. Res. 10(2): 250-252, 1980.

[14] M.M. Rahman, M.A. Mannan, and M.A. Islam, "Pest survey of major summer and winter pulses in Bangladesh", In the proceedings of the National Workshop on Pulses. (eds.) A. K. Kaul, pp. 265-273. 1981.

[15] K.M. Srivastava, L.N. Singh, “A review of the pest complex of kharif pulses in Uttar Pradesh (U.P.)” PANS. 22(3), 333-335, 1976

[16] K. S. Chhabra, B. S. Kooner, "Problem of flower shedding caused by thrips, Megalurothripsdistalis (Karny), on summer mungbean, Vigna radiate (L) Wilczek, and its control". Trop. Pest Management. 31(3): 186-188, 1985

[17] M.R.G.K. Nair, "Insects and Mites of Crops in India”, Indian Council of Agric. Res. New Delhi, 408p, 1986

[18] M.M. Rahman, "Control measures for important insect pests of major pulses, pp. 139-146, In Proceedings of the Second National Workshop on Advances in Pulses Research in Bangladesh, 6-8 June 1989, Joydepur Bangladesh. Ptancheru, A. P. 502 324, India”. International Crops Research Institute for the Semi-Arid Tropics, 1991

[19] H. Kajita, M.Z. Alam, "Whiteflies on guava and vegetables in Bangladesh and their Aphelinid parasitoids". Appl. Entomol. Zool. 31(1), 159-162, 1996

[20] M.M. Rahman, "Efficacy of some promising insecticides on pest incidence, plant growth and grain yield of cowpea", Tropical Grain Legume Bulletin. 35: 19-22, 1988

[21] M.M. Rahman, "Efficacy of some promising insecticides on pest incidence, plant growth and grain yield of cowpea". Tropical Grain Legume Bulletin. 35: 19-22, 1989

[22] M. Sreekant, M. Sreeramulu, R.D.V.J.P. Rao, B.S. Babu, T.R. Babu, "Effect of intercropping on Thripspalmi(Karny) population and peanut bud necrosis virus (PBNV) incidence in mungbean (Vignaradiata)". Indian J. Plant Protect. 32(10), 45-48, 2004

[23] S. Jayaraj, "Nonchemical management methods of some key mungbean pests. In: Shanmugasundaram, S. (ed.)" Mungbean: Proceedings of the Second International symposium on Mungbean. 16-20 November 1987. Bankok, Thailand AVRDC, Shanhua, Tainan, Taiwan (ROC), p367, 1988

[24] B. Rajasekaran, T. Kumaraswami, "Antifeeding properties of certain plant products against Spodopteralitura (F)", Pages 25-28. In A, Regdupathy, and S. Jayaraj, eds. Behavioural and Physiological Approaches in Management of Crop Pests, Tamil Nadu Agric. Univ. Coimbatore, 1985

[25] N.A. Khan, H.R. Ansari, Samiullah, "Effect of gibberellic acid spray and basal nitrogen and phosphorus on productivity and fatty acid composition of rapeseed-mustard”, J. Agron. Crop Sci. 179: 29-33, 1997

[26] UNDP, FAO, "Land Resources Appraisal of Bangladesh for Agricultural Development. Report 2, Agroecological Regions of Bangladesh". United Nations Development Programme and Food and Agriculture Organization, pp. 212-221, 1988

[27] BARI (Bangladesh Agriculture Research Institute), "KrishiProjuktiHatboi (in Bangla)". 4th ed., Bangladesh Agril. Res. Inst., Gazipur, Bangladesh, p. 209-211, 2006

[28] G. Musatafa, "Annul Rept. Emtomol. Section", AyubAgric, Res. Institute, Faisalabad, pp. 1-14, 2000

[29] M. Mohan, K.N. Katiyar, "Impact of different insecticides used for bollworm control on the population of jassids and whitefly on cotton", J. Pestic. Res. 12 (1), $99-102,2000$

[30] T. Ganapathy, R. Karuppiah, "Evaluation of new insecticides for the management of whitefly (BemisiatabaciGenn.), mungbean yellow mosaic virus (MYMV) and urdbean leaf crinkle virus (ULCV) diseases in mungbean (Vignaradiata(L.) Wilezek)", Indian J. Plant Protec. 32(1), 35-38, 2004 
[31] M. Jahangir Shah, A. Ahmad, M. Hussain, M. Malik, Yousaf, B. Ahmad, "Efficiency of different insecticides against sucking insect-pest complex and effect on the growth and yield of mungbean (Vigna radiata L.)". Pakistan Entomol. 29(2), 83-86, 2007

[32] D.F. Russell, “MSTAT-C package programme”, Dept. Crop Soil Sci. Michigian State Univ. USA, p. 59-60, 1986

[33] K.A. Gomez, A.A. Gomez, "Statistical procedures for Agricultural Research", A Wiley Int. Sci. Publ. John Wiley and Sons. New York, Brisbane, Singapore, pp. 139-240, 1984

\section{APPENDICES}

Appendix I: Physical characteristics of field soil analyzed in Soil Resources Development Institute (SRDI) laboratory, Khamarbari, Farmgate, Dhaka

\begin{tabular}{|c|c|}
\hline Characteristics & Value \\
\hline \% Sand & 27 \\
\hline \% Silt & 43 \\
\hline \% clay & Silty -clay \\
\hline Textural class & 5.6 \\
\hline pH & 0.45 \\
\hline Organic carbon (\%) & 0.78 \\
\hline Organic matter (\%) & 0.03 \\
\hline Total N (\%) & 20 \\
\hline Available P (ppm) & 0.1 \\
\hline Exchangeable K (me $/ 100$ g soil) & 45 \\
\hline Available S (ppm) & 20 \\
\hline
\end{tabular}

Source: Soil Resources Development Institute (SRDI)

Appendix II: Monthly record of air temperature, relative humidity, rainfall, and sunshine of the experimental site during the period from March to June 2014

\begin{tabular}{|c|c|c|c|c|c|}
\hline \multirow{2}{*}{ Month (2012) } & \multicolumn{2}{|c|}{${ }^{*}$ Air temperature $\left({ }^{o} \mathrm{c}\right)$} & \multirow{2}{*}{$\begin{array}{c}* \text { Relative } \\
\text { humidity (\%) }\end{array}$} & \multirow{2}{*}{$\begin{array}{c}* \text { Rainfall total } \\
(\mathrm{mm})\end{array}$} & \multirow{2}{*}{$\begin{array}{c}\text { *Sunshine } \\
\text { (hr) }\end{array}$} \\
\hline & Maximum & Minimum & & & \\
\hline March & 31.4 & 19.6 & 54 & 11 & 8.2 \\
\hline May & 34.7 & 25.9 & 70 & 185 & 7.8 \\
\hline June & 35.4 & 28.6 & 75 & 242 & 7.5 \\
\hline
\end{tabular}

* Monthly average,

[1] Source: Bangladesh Meteorological Department (Climate \& weather division) Agargoan, Dhaka - 1212 